\title{
PENGETAHUAN DAN SIKAP REMAJA PUTRI TENTANG KEKERASAN PEREMPUAN DAN DAMPAKNYA TERHADAP KESEHATAN REPRODUKSI DI KOTA DENPASAR TAHUN 2017
}

\author{
Gusti Ayu Purnama Dewi*, Ni Made Dian Kurniasari, I Ketut Tangking Widarsa \\ Program Studi Kesehatan Masyarakat Fakultas Kedokteran Universitas Udayana \\ *Email:ayuwarsi@gmail.com
}

\begin{abstract}
ABSTRAK
Kekerasan terhadap perempuan merupakan masalah kesehatan masyarakat karena berdampak pada kesehatan reproduksi. Prevalensi kekerasan perempuan di dunia maupun di Indonesia mengalami peningkatan dari tahun ke tahun. Peningkatan kasus kekerasan dapat disebabkan oleh faktor seperti pengetahuan dan sikap. Tujuan dari penelitian ini adalah untuk mengetahui tingkat pengetahuan dan sikap remaja putri tentang kekerasan perempuan dan dampaknya terhadap kesehatan reproduksi di Kota Denpasar Tahun 2017.Penelitian ini merupakan penelitian deskriptif kuantitatif dengan rancangan cross-sectional. Sampel penelitian adalah 96 siswi kelas VII dan VIII SMP yang dipilih dengan teknik multistage random sampling dan simple random sampling. Pengumpulan data pengetahuan dan sikap dilakukan dengan menggunakan kuesioner terstuktur dan data dianalisis secara deskriptif.Hasil penelitian didapatkan 78,1\% remaja putri memiliki pengetahuan baik, 15,6\% memiliki pengetahuan cukup, dan 6,3\% memiliki pengetahuan kurang. Hasil untuk sikap terhadap kekerasan perempuan didapatkan 67,7\% remaja putri memiliki sikap baik dan 32,3\% memiliki sikap cukup. Dapat disimpulkan bahwa sebagian besar remaja putri memiliki tingkat pengetahuan baik serta lebih dari setengah memiliki sikap menolak kekerasan perempuan. Disarankan kepada pihak sekolah untuk meningkatkan peran guru BK dan juga mengaktifkan peran PIK-R dalam upaya meningkatkan pemahaman para remaja tentang dampak negatif jangka panjang dari kekerasan, sehingga para remaja tersebut memiliki keberanian untuk melapor bila menjadi korban kekerasan dikemudian hari.
\end{abstract}

Kata Kunci: pengetahuan, sikap, kekerasan terhadap perempuan (KtP), kesehatan reproduksi, remaja putri

\begin{abstract}
Violence against women is a public health problem because it impacts reproductive health. The prevalence of female violence in the world and in Indonesia has increased from year to year. Increased cases of violence can be caused by factors such as knowledge and attitudes. The purpose of this study was to determine the knowledge and attitudes level of young women about female violence and its impact on reproductive health in Denpasar City in 2017. This research is a quantitative descriptive study with cross-sectional design. The research sample was 96 class VII and VIII junior high school students, who selected by multistage random sampling and simple random sampling techniques. Knowledge and attitude data collection was carried out using a structured questionnaire and the data were analyzed descriptively. The results showed $78.1 \%$ of young women had good knowledge, $15.6 \%$ had sufficient knowledge, and 6.3\% had less knowledge. The results for attitudes towards female violence obtained $67.7 \%$ of young women had good attitudes and $32.3 \%$ had sufficient attitudes. It can be concluded that the majority of young women have a good level of knowledge and more than half have attitudes to resist female violence. It is suggested to the school to increase the role of BK teachers and also activate the role of PIK-R in an effort to increase the understanding of adolescents about the long-term negative effects of violence, so that these youth have the courage to report if they become victims of violence in the future.
\end{abstract}

Keywords: knowledge, attitudes, violence against women $(\mathrm{KtP})$, reproductive health, adolescent girls

\section{PENDAHULUAN}

Kekerasan terhadap perempuan menjadi salah satu perhatian utama dari World Health Organization (WHO) dan Sustainable Development Goals (SDGs) karena angka kejadiannya yang tinggi dan dampaknya terhadap kesehatan perempuan (WHO, 2013). Laporan WHO pada tahun 2013 menyatakan bahwa 35\% perempuan di seluruh dunia mengalami kekerasan. Di 
Indonesia prevalensi kekerasan perempuan pada tahun 2006 sebesar 3\% (Kementerian Kesehatan RI, 2010). Angka tersebut mengalami kenaikan menjadi $11 \%$ pada tahun 2011 (Hasanah, 2013). Berdasarkan survei kekerasan terhadap anak di Indonesia tahun 2013, didapatkan sebanyak 35\% remaja perempuan usia 18-24 tahun mengalami setidaknya satu bentuk kekerasan sebelum usia 18 tahun (Kementerian Sosial RI, 2014). Kekerasan perempuan juga terjadi di Kota Denpasar, dimana ada peningkatan kasus kekerasan terhadap perempuan yang dilaporkan ke BP3A Provinsi Bali (BP3A, 2015).

Kekerasan pada perempuan akan berdampak terhadap kesehatan fisik, mental, seksual dan reproduksi. Perempuan yang mengalami kekerasan dua kali lebih berpotensi untuk mengalami depresi (WHO, 2016). Selain itu, perempuan yang mengalami kekerasan seksual dari pasangannya 1,5 kali lebih berpeluang menderita infeksi menular seksual (IMS) termasuk Human Immunodeficiency Virus (HIV), dua kali lebih memungkinkan untuk melakukan aborsi serta sebanyak $16 \%$ dari perempuan yang mengalami kekerasan juga berpotensi memiliki bayi berat lahir rendah (WHO, 2013).

Ada beberapa faktor yang menyebabkan perempuan mengalami kekerasan dari pasangannya, diantaranya pendidikan yang rendah dan sikap menerima kekerasan (WHO, 2012). Survei di Australia pada tahun 2013 menyatakan bahwa pengetahuan tentang kekerasan memberikan pengaruh kuat pada sikap remaja terhadap kekerasan perempuan (VicHealth, 2015). Penelitian Hayati et al
(2011) menyatakan bahwa sikap perempuan terhadap kekerasan akan mempengaruhi tindakan mereka untuk melaporkan kejadian kekerasan tersebut.

Pada masa remaja terutama remaja awal (10-14 tahun) perlu diberikan semua informasi kesehatan termasuk informasi tentang kekerasan perempuan sehingga para remaja dapat mempersiapkan dirinya agar terhindar dari tindakan kekerasan dikemudian hari (UNICEF, 2011). Penelitian ini bertujuan untuk mengetahui tingkat pengetahuan dan sikap remaja putri tentang kekerasan perempuan dan dampaknya terhadap kesehatan reproduksi di Kota Denpasar Tahun 2017.

\section{METODE}

Penelitian ini adalah penelitian deskriptif kuantitatif dengan rancangan cross-sectional. Penelitian ini dilaksanakan pada Sekolah Menengah Pertama (SMP) di Kota Denpasar dengan jumlah sampel sebanyak 96 siswi kelas VII dan VIII. Pemilihan sekolah dilakukan dengan teknik multistage random sampling kemudian pemilihan sampel individu dilakukan secara simple random sampling. Data pengetahuan dan sikap dikumpulkan dengan menggunakan kuesioner. Data yang telah terkumpul dianalisis secara univariat.

\section{HASIL}

\section{Karakteristik Remaja Putri}

Karakteristik remaja putri dalam penelitian ini meliputi umur, pernah atau tidak pernah mendapatkan informasi dan sumber-sumber informasi yang dapat dilihat pada tabel berikut ini: 
Tabel 1. Karakteristik Remaja Putri

\begin{tabular}{lrc}
\hline Karakteristik & F & (\%) \\
\hline Umur & 16 & 16,7 \\
12 tahun & 35 & 36,4 \\
13 tahun & 41 & 42,7 \\
14 tahun & 4 & 4,2 \\
15 tahun & & \\
Pernah Mendapatkan Informasi & & \\
Pernah & 93 & 96,9 \\
Tidak Pernah & 3 & 3,1 \\
Sumber Informasi* & & \\
Keluarga & 33 & 34,4 \\
Teman & 22 & 22,9 \\
Guru & 26 & 27,1 \\
Tenaga Kesehatan & 31 & 32,3 \\
Media Massa & 74 & 77,1 \\
\hline
\end{tabular}

${ }^{*}$ Responden dapat menjawab lebih dari 1 paling banyak didapatkan dari media massa sumber informasi

Dari 96 remaja putri yang menjadi responden, mayoritas berumur 13-14 tahun $(77,1 \%)$ sedangkan paling sedikit didapatkan dari teman sebaya $(22,9 \%)$. (79,1\%). Sebagian besar remaja putri pernah mendapatkan informasi tentang kekerasan perempuan (96,9\%), dimana informasi

\section{Pengetahuan Remaja Putri}

Tingkat pengetahuan remaja putri dikategorikan menjadi tiga yaitu pengetahuan baik, cukup dan kurang.

Tabel 2. Pengetahuan Remaja Putri

\begin{tabular}{lclc}
\hline Pengetahuan & Frekuensi & (\%) \\
\hline Baik & 75 & 78,1 \\
Cukup & 15 & 15,6 \\
Kurang & 6 & 6,3 \\
\hline Total & 96 & 100,0 \\
\hline \multicolumn{3}{r}{ Berdasarkan Tabel 2 di atas sebagian } & mempunyai pengetahuan yang baik tentang \\
besar remaja putri memiliki pengetahuan & definisi kekerasan perempuan, faktor-faktor \\
yang baik tentang kekerasan perempuan & penyebab dan dampaknya terhadap \\
dan dampaknya terhadap kesehatan & kesehatan reproduksi, namun masih ada \\
reproduksi (78,1\%). Hanya 6,3\% remaja putri & sebagian remaja putri yang kurang \\
yang memiliki tingkat pengetahuan kurang. & mengetahui tentang sikap mengekang. Dari \\
Dilihat dari komponen pengetahuan & 96 remaja putri hanya sebanyak 64,6\% yang \\
sebagian besar remaja putri sudah & mengetahui bahwa sikap mengekang juga
\end{tabular}


merupakan bentuk kekerasan perempuan ini:

seperti yang disajikan dalam Tabel 3 berikut

Tabel 3. Pengetahuan tentang Kekerasan Perempuan

\begin{tabular}{|c|c|c|c|}
\hline \multirow{2}{*}{ No. Soal } & \multirow{2}{*}{ Pengetahuan tentang Kekerasan Perempuan } & \multicolumn{2}{|c|}{ Jawaban Benar } \\
\hline & & (f) & $(\%)$ \\
\hline \multicolumn{4}{|c|}{ Definisi kekerasan perempuan: } \\
\hline 1. & Kekerasan dapat terjadi dalam hubungan pacaran & 83 & 86,5 \\
\hline 2. & Kekerasan dapat terjadi dalam rumah tangga & 87 & 90,6 \\
\hline \multicolumn{4}{|c|}{ Bentuk-bentuk kekerasan perempuan: } \\
\hline 3. & Membentak, berteriak dan berkata kasar & 74 & 77,1 \\
\hline 4. & Pemaksaan berhubungan seksual & 90 & 93,8 \\
\hline 5. & Sikap mengekang & 62 & 64,6 \\
\hline \multicolumn{4}{|c|}{ Faktor-faktor penyebab kekerasan perempuan: } \\
\hline 6. & Penggunaan alkohol dan obat terlarang & 86 & 89,6 \\
\hline 7. & Pernah mengalami kekerasan semasa kanak-kanak & 76 & 79,2 \\
\hline \multicolumn{4}{|c|}{ Dampak kekerasan perempuan terhadap kesehatan reproduksi: } \\
\hline 8. & Luka dan cedera & 94 & 97,9 \\
\hline 9. & Memar dan patah tulang & 86 & 89,6 \\
\hline 10. & Kecemasan dan gangguan emosi & 79 & 82,3 \\
\hline 11. & Stress dan depresi & 85 & 88,5 \\
\hline 12. & Kekerasan berdampak pada kesehatan reproduksi & 83 & 86,5 \\
\hline 13. & Penularan HIV/AIDS & 90 & 93,8 \\
\hline 14. & Dapat mengakibatkan IMS & 88 & 91,7 \\
\hline 15. & Dapat mengakibatkan ISK & 85 & 88,5 \\
\hline 16. & Dapat mengakibatkan KTD & 96 & 100,0 \\
\hline
\end{tabular}

\section{Sikap Remaja Putri}

Tabel 4. Sikap Remaja Putri

\begin{tabular}{lcc}
\hline Sikap & Frekuensi & $\mathbf{( \% )}$ \\
\hline Baik & 65 & 67,7 \\
Cukup & 31 & 32,3 \\
Kurang & 0 & 0,0 \\
\hline Total & 96 & 100,0 \\
\hline
\end{tabular}

Berdasarkan Tabel 4 di atas lebih dari setengah remaja putri memiliki sikap yang baik terhadap kekerasan perempuan $(67,7 \%)$ dan tidak ada remaja putri yang memiliki sikap kurang. Dilihat dari komponen sikap masih ada sebagian besar remaja putri yang merasa malu jika kekerasan yang dialaminya diketahui oleh orang lain. Dari 96 remaja putri sebanyak $70,8 \%$ malu jika orang lain mengetahui kekerasan yang mereka alami 
seperti yang disajikan dalam Tabel 5 berikut ini:

Tabel 5. Sikap terhadap Kekerasan Perempuan

\begin{tabular}{|c|c|c|c|}
\hline No. Soal & $\begin{array}{c}\text { Sikap terhadap Kekerasan } \\
\text { Perempuan }\end{array}$ & $\begin{array}{l}\text { Setuju } \\
\text { f (\%) }\end{array}$ & $\begin{array}{c}\text { Tidak Setuju } \\
\text { f ( } \%)\end{array}$ \\
\hline \multirow[t]{2}{*}{1.} & Memukul untuk menyelesaikan & & \\
\hline & konflik & $3(3,1)$ & $93(96,9)$ \\
\hline \multirow[t]{2}{*}{2.} & Pasangan berhak menghina & & \\
\hline & & $18(18,8)$ & $78(81,2)$ \\
\hline \multirow[t]{2}{*}{3.} & Pasangan berhak membentak & & \\
\hline & & $17(17,7)$ & $79(82,3)$ \\
\hline \multirow[t]{2}{*}{4.} & Pasangan berhak mengatur hidup & & \\
\hline & & $14(14,6)$ & $82(85,4)$ \\
\hline \multirow[t]{2}{*}{5.} & Masalah pribadi yang boleh & & \\
\hline & diceritakan & $64(66,7)$ & $32(33,3)$ \\
\hline \multirow[t]{2}{*}{6.} & Malu jika orang lain mengetahui & & \\
\hline & & $68(70,8)$ & $28(29,2)$ \\
\hline \multirow[t]{2}{*}{7.} & Menerima bila ditampar & & \\
\hline & & $2(2,1)$ & $94(97,9)$ \\
\hline \multirow[t]{3}{*}{8.} & Menerima bila diberikan kata-kata & & \\
\hline & kasar & & \\
\hline & & $2(2,1)$ & $94(97,9)$ \\
\hline \multirow[t]{2}{*}{9.} & Menerima bila diancam & & \\
\hline & & $2(2,1)$ & $94(97,9)$ \\
\hline \multirow[t]{2}{*}{10.} & Mencari bantuan bila mengalami & & \\
\hline & kekerasan & $88(91,7)$ & $8(8,3)$ \\
\hline \multirow[t]{2}{*}{11.} & Boleh melapor ke polisi & & \\
\hline & & $91(94,8)$ & $5(5,2)$ \\
\hline
\end{tabular}

Pengetahuan dan Sikap Remaja Putri

Tabel 6. Pengetahuan dan Sikap Remaja Putri

\begin{tabular}{lrrr}
\hline $\begin{array}{l}\text { Pengetahuan Tentang } \\
\text { Kekerasan Perempuan }\end{array}$ & \multicolumn{2}{c}{ Sikap Terhadap Kekerasan Perempuan } & \multirow{2}{*}{ Total } \\
\hline Baik & Baik (\%) & Cukup (\%) & \\
Cukup & $54(72,0)$ & $21(28,0)$ & $75(100,0)$ \\
Kurang & $9(60,0)$ & $6(40,0)$ & $15(100,0)$ \\
\hline
\end{tabular}




\begin{tabular}{l} 
Total \\
\hline Berdasarkan tabel di atas dapat \\
dilihat bahwa sebagian besar remaja putri \\
dengan pengetahuan baik tentang kekerasan \\
perempuan memiliki sikap yang baik juga \\
terhadap kekerasan perempuan. Dari 75 \\
remaja putri dengan tingkat pengetahuan \\
baik tentang kekerasan perempuan \\
sebanyak $72,0 \%$ memiliki sikap baik \\
terhadap kekerasan perempuan.
\end{tabular}

\section{DISKUSI}

Pengetahuan Remaja Putri Tentang Kekerasan Perempuan dan Dampaknya

Terhadap Kesehatan Reproduksi

Hasil dari penelitian ini menunjukkan bahwa sebagian besar remaja putri di Kota Denpasar memiliki pengetahuan yang baik tentang kekerasan perempuan dan dampaknya terhadap kesehatan reproduksi. Hasil penelitian ini sejalan dengan penelitian yang dilakukan oleh Izati dan Sasongko (2012) terhadap siswa kelas XI SMA di Jakarta yang mendapatkan hasil tingkat pengetahuan remaja tentang kekerasan dalam pacaran pada kategori tinggi sebesar 63,8\%. Penelitian dari Utari (2016) mendapatkan hasil bahwa tingkat pengetahuan ibu di Kalirejo Ungaran Timur tentang kekerasan dalam rumah tangga pada kategori baik yaitu sebesar $87,2 \%$. Tingkat pengetahuan yang memadai tersebut dapat disebabkan karena paparan informasi yang pernah didapatkan oleh para perempuan tersebut sehingga sebagian besar dari mereka memiliki pengetahuan yang baik. Hal ini sesuai dengan teori dari Notoatmodjo (2007)

$31(32,3) \quad 96(100,0)$

yang menyatakan bahwa informasi mempengaruhi tingkat pengetahuan seseorang, semakin banyak seseorang memperoleh informasi maka semakin luas pengetahuannya.

Sementara itu hasil penelitian dari Anantri (2015) pada remaja putri di Semarang mendapatkan hasil tingkat pengetahuan tentang kekerasan dalam pacaran pada kategori kurang (62,4\%). Tingkat pengetahuan yang kurang tersebut dapat disebabkan karena kurangnya informasi dan edukasi yang didapatkan oleh para remaja putri di Semarang serta kurang dikembangkannya pelayanan kesehatan yang ramah remaja di daerah tersebut (Anantri, 2015). Hal ini tentu berbeda dengan yang terjadi di Kota Denpasar dimana para remaja putri sudah pernah mendapatkan informasi dan edukasi tentang kesehatan reproduksi dari tenaga kesehatan melalui penyuluhan ke sekolah-sekolah. Selain itu, di Bali telah terdapat program pelayanan kesehatan ramah remaja yang dikembangkan oleh PKBI Bali yaitu KISARA (Kita Sayang Remaja).

Akses remaja putri saat ini terhadap sumber-sumber informasi terkait kekerasan perempuan dan kesehatan reproduksi sangatlah mudah dengan adanya media massa, KISARA, Pusat Informasi dan Konseling Remaja (PIK-R), Kelompok Siswa Peduli AIDS dan Narkoba (KSPAN) serta program penyuluhan dari para tenaga kesehatan. Hal tersebut dapat dilihat dari adanya ekstrakurikuler KSPAN dan PIK-R di tiap sekolah, namun dalam pelaksanaannya hanya ekstrakurikuler KSPAN yang cukup aktif dilakukan 
sedangkan PIK-R belum begitu aktif dilakukan. Demikian pula dengan program penyuluhan oleh para tenaga kesehatan dari puskesmas setempat dimana penyuluhan yang diberikan kepada para remaja belum terlaksana secara teratur dan terjadwal.

Dalam penelitian ini sumber informasi tentang kekerasan perempuan paling sedikit didapatkan dari teman sebaya, padahal menurut hasil penelitian dari Budiarti (2015) terdapat hubungan antara peran teman sebaya dengan kejadian kekerasan dalam pacaran. Penelitian dari Ariestina (2009) juga menyatakan teman sebaya sebagai kelompok yang banyak memberikan pengaruh kepada para remaja. Hasil tersebut menunjukkan bahwa teman sebaya berpotensi untuk menyebarkan informasi-informasi tentang kesehatan reproduksi terutama tentang kekerasan perempuan. Selain itu, tidak hanya remaja putri yang perlu mengetahui informasi tentang kekerasan perempuan namun juga perlu bagi para remaja putra untuk mendapatkan informasi dan edukasi tentang kekerasan perempuan sehingga para remaja putra dapat memahami masalah kekerasan yang terjadi di masyarakat, dapat mencegah dirinya melakukan kekerasan dikemudian hari serta dapat membantu dan mendukung remaja putri yang mengalami kekerasan untuk melaporkan kekerasan yang dialaminya.

Selain dari teman sebaya, sumber informasi remaja putri dalam penelitian ini juga sedikit didapatkan dari guru. Hanya sebanyak 27,1\% dari 96 remaja putri yang menyatakan pernah mendapatkan informasi tentang kekerasan perempuan dari guru di sekolah. Menurut Noerjoedianto dan
Herwansyah (2012) para remaja kadangkadang berinteraksi tentang topik kesehatan reproduksi remaja dengan guru di sekolah namun ada juga remaja yang tidak pernah sama sekali berinteraksi dengan guru di sekolahnya. Hal tersebut dikarenakan remaja menganggap kesehatan reproduksi merupakan hal yang tabu untuk dibicarakan dan ditanyakan kepada guru di sekolah. Untuk itu para guru di sekolah terutama guru Bimbingan dan Konseling (BK) perlu meningkatkan perannya dalam membimbing para remaja yang menjadi siswa didiknya sehingga para remaja tersebut tidak lagi takut untuk membahas masalah kesehatan reproduksi yang dialaminya dengan gurunya.

Dalam penelitian ini masih terdapat sebanyak 35,4\% remaja putri yang tidak mengetahui bahwa sikap mengekang yang dilakukan oleh pasangan termasuk salah satu bentuk dari kekerasan perempuan. Ketidaktahuan tersebut mungkin disebabkan karena budaya patriarki yang dianut oleh masyarakat Indonesia dimana masyarakat masih menganggap sikap mengekang dan mengatur hidup perempuan adalah suatu hal yang wajar untuk dilakukan dan juga norma di masyarakat yang memperbolehkan laki-laki untuk mengontrol perempuan (Izati dan Sasongko, 2012). Selain itu menurut Ariestina (2009) para remaja kebanyakan memiliki perasaan sayang yang berlebihan pada pasangannya sehingga sikap mengekang yang dilakukan oleh pasangannya kemudian dianggap sebagai bentuk kasih sayang.

Sikap Remaja Putri Terhadap Kekerasan Perempuan 
Hasil dari penelitian ini menunjukkan bahwa lebih dari setengah remaja putri di Kota Denpasar memiliki sikap baik terhadap kekerasan perempuan, artinya para remaja putri tersebut tidak setuju atau menolak tindakan kekerasan pada perempuan. Hasil tersebut sejalan dengan penelitian dari Ariestina (2009) yang menyatakan bahwa 54,8\% siswi SMA di Jakarta memiliki sikap menolak kekerasan dalam pacaran. Penelitian dari Yusuf (2014) terhadap sikap siswi SMK di Kulon Progo juga mendapatkan hasil sebesar 55,9\% siswi menolak tindakan kekerasan dalam pacaran. Dalam penelitian ini juga didapatkan hasil bahwa sebagian besar remaja putri dengan pengetahuan baik tentang kekerasan perempuan memiliki sikap yang baik pula terhadap kekerasan perempuan. Hasil yang baik ini disebabkan karena para remaja putri tersebut sudah mendapatkan pendidikan dan informasi tentang kekerasan perempuan sehingga terbentuk pengetahuan dan sikap yang baik terhadap kekerasan perempuan. Hal ini sesuai dengan teori dari Walgito bahwa pengetahuan mempengaruhi pembentukan sikap (Kusumastuti, 2010). Selain itu Azwar dalam Wawan dan Dewi (2011) juga menyatakan bahwa pendidikan memiliki pengaruh dalam pembentukan sikap.

Berdasarkan hasil penelitian sebagian besar remaja putri menyatakan malu jika orang lain mengetahui kekerasan yang dialaminya dan masih terdapat remaja putri yang menyatakan bahwa kekerasan merupakan masalah pribadi yang tidak boleh diceritakan kepada siapapun. Meskipun para remaja putri sudah memiliki sikap menolak kekerasan perempuan namun masih banyak pula yang memiliki sifat malu untuk menceritakan kejadian kekerasan yang dialaminya. Hal ini disebabkan karena faktor psikososial yang ada didalam diri remaja dimana mereka menganggap kekerasan merupakan aib pada diri mereka sehingga menjadi hal yang tabu untuk dibicarakan kepada orang lain. Selain itu, mereka juga memiliki rasa tidak percaya kepada orang lain karena meragukan kerahasiaan dari masalah yang dibicarakan (Yani, 2014). Sifat malu juga akan membuat remaja putri menjadi tidak memiliki keberanian untuk melaporkan kekerasan tersebut kepada pihak berwajib dan juga akan menyulitkan orangtua, guru ataupun teman sebaya dalam memberikan nasihat dan bantuan (Anantri, 2015). Perempuan korban kekerasan yang tidak menceritakan dan tidak melaporkan kejadian kekerasan yang dialaminya akan mengalami beberapa dampak negatif pada kesehatan psikologisnya seperti merasa bersalah, merasa depresi, mengalami kecemasan dan ketakutan di dalam dirinya yang kemudian dapat mengakibatkan penurunan derajat kesehatan. Tidak dilaporkannya kejadian kekerasan yang dialami oleh perempuan juga menyebabkan kekerasan terhadap perempuan terus menerus menjadi fenomena gunung es (Komnas Perempuan, 2016). Oleh karena itu, untuk membuat para remaja putri mau menceritakan dan melaporkan masalah kekerasan yang dialaminya mereka perlu diberikan pemahaman lebih dalam tentang dampak negatif yang ditimbulkan akibat kekerasan perempuan dan juga mendapatkan jaminan dari tenaga kesehatan ataupun dari konselor 
tentang kerahasiaan dari masalah yang diceritakan kepada mereka.

\section{SIMPULAN}

Sebagian besar remaja putri $(78,1 \%)$ memiliki tingkat pengetahuan baik tentang kekerasan perempuan dan dampaknya terhadap kesehatan reproduksi namun masih ada bentuk-bentuk kekerasan perempuan yang belum diketahui oleh para remaja putri. Lebih dari setengah remaja putri $(67,7 \%)$ memiliki sikap menolak kekerasan perempuan namun masih terdapat remaja putri yang malu untuk menceritakan dan melaporkan kejadian kekerasan yang dialaminya.

Diharapkan kepada pihak sekolah untuk meningkatkan pengetahuan dan pemahaman para remaja putri maupun remaja putra terhadap aspek bentuk-bentuk kekerasan perempuan dan juga dampak negatif dari kekerasan perempuan baik melalui pembelajaran intrakurikuler yaitu pelajaran kesehatan reproduksi, melalui pembelajaran ekstrakurikuler yaitu KSPAN dan PIK-R, melalui kegiatan pihak ke tiga yaitu KISARA, maupun melalui bimbingan dan konseling dengan guru BK sehingga para remaja dapat melindungi dirinya sendiri dari kekerasan dan mau melaporkan bila mengalami kekerasan dikemudian hari.

\section{DAFTAR PUSTAKA}

Anantri, Khansa Maulidta. (2015). Analisis Faktor-Faktor yang Mempengaruhi Remaja Putri Terhadap Perilaku Kekerasan dalam Pacaran di SMA " $X$ " Kota Semarang. Jurnal Kesehatan Masyarakat, 3 (3): 908-917.

Ariestina, Dian. (2009). Kekerasan dalam Pacaran pada Siswi SMA di Jakarta.
Jurnal Kesehatan Masyarakat Nasional, 3 (4): 161-170.

BP3A. (2014). Data Kasus Kekerasan di Provinsi Bali [data tidak dipublikasikan].

BP3A. (2015). Data Kasus Kekerasan di Provinsi Bali [data tidak dipublikasikan].

Budiarti, Indah. (2015). Hubungan Peran Teman Sebaya (Peers) dengan Kejadian Kekerasan dalam Pacaran di SMA N 1 Sanden Bantul. Yogyakarta: STIKES 'Aisyiyah Yogyakarta.

Hasanah, Hasyim. (2013). Kekerasan terhadap Perempuan dan Anak dalam Rumah Tangga Perspektif Pemberitaan Media. SAWWA, 9 (1): 159-178.

Hayati et al. (2011). Behind the silence of harmony: risk factors for physical and sexual violence among women in rural Indonesia. BMC Women's Health, 2011 11:52.

Izati, Nurul dan Sasongko, Adi. (2012). Hubungan Pengetahuan dan Sikap Terhadap Kekerasan dalam Pacaran pada Siswa Kelas XI SMA Negeri 113 Jakarta Tahun 2012. Jakarta: FKM Universitas Indonesia.

Kementerian Kesehatan RI. (2010). Pedoman Pengembangan Puskesmas Mampu Tata Laksana Kasus Kekerasan terhadap Perempuan dan Anak. Jakarta: Kementerian Kesehatan RI.

Kementerian Sosial RI. (2014). Ringkasan Hasil Survey Kekerasan terhadap Anak Indonesia Tahun 2013. Available: http://puslit.kemsos.go.id/download/2 90 (Accessed: 2017, Pebruari 5).

Komnas Perempuan. (2016). Kekerasan terhadap Perempuan Meluas: Negara 
Urgen Hadir Hentikan Kekerasan terhadap Perempuan di Ranah Domestik, Komunitas dan Negara. Available: http://www.komnasperempuan.go.id/ wp-

content/uploads/2016/03/KOMNASPEREMPUAN-_-CATATAN-

TAHUNAN-2016edisi-Launching-7Maret-2016.pdf (Accessed: 2017, Januari 30).

Kusumastuti, Fadhila Arbi Dyah. (2010). Hubungan antara Pengetahuan dengan Sikap Seksual Pranikah Remaja. Surakarta: FK Universitas Sebelas Maret.

Noerjoedianto, Dwi dan Herwansyah. (2012). Survey Perilaku Kesehatan Remaja Siswa SMA Negeri 5 Kota Jambi Tahun 2012. JMJ, 2 (1): 65-77.

Notoatmodjo, S. (2007). Pengantar Promosi Kesehatan dan Aplikasi Ilmu Prilaku. Jakarta: Rineka Cipta.

UNICEF. (2011). Adolescence an Age of Opportunity. Available: https://www.unicef.org/adolescence/fil es/SOWC_2011_Main_Report_EN_020 92011.pdf (Accessed: 2017, Januari 31).

Utari, Nyemas Sindya. (2016). Hubungan Pengetahuan dengan Kejadian Kekerasan dalam Rumah Tangga pada Ibu di Kalirejo Ungaran Timur Kabupaten Semarang. Prosiding Seminar Nasional Kebidanan dan Call for Paper: 373-384.

VicHealth. (2015). Survey Summary: Young Australians' attitudes to violence against women. Australia: Victoria State Government.

Wawan dan Dewi. (2011). Teori $\mathcal{E}$ Pengukuran Pengetahuan, Sikap dan
Perilaku Manusia. Yogyakarta: Nuha Medika.

WHO. (2012). Understanding and addressing violence against women. Available: http://apps.who.int/iris/bitstream/1066 5/77432/1/WHO_RHR_12.36_eng.pdf (Accessed: 2016, Desember 10).

WHO. (2013). Global and Regional Estimates of Violence against Women: Prevalence and Health Effects of Intimate Partner Violence and Nonpartner Sexual Violence. Available:

http://apps.who.int/iris/bitstream/1066 5/85239/1/9789241564625_eng.pdf

(Accessed: 2016, Desember 26).

WHO. (2016). Violence against women. Available:

http://www.who.int/mediacentre/facts heets/fs239/en/ (Accessed: 2017, Januari 10).

Yani, Vella Dwi. (2014). Persepsi Remaja Terhadap Faktor Penghambat Pemanfaatan Pelayanan Kesehatan Reproduksi di Puskesmas Gambok Kabupaten Sijunjung. Jurnal Kesehatan Reproduksi, 1 (1).

Yusuf, Nuuva. (2014). Hubungan Persepsi Remaja Tentang Kekerasan dengan Sikap Terhadap Kekerasan dalam Pacaran pada Siswi di SMK Negeri Nanggulan Kulon Progo. Yogyakarta: STIKES 'Aisyiyah Yogyakarta. 